\title{
The Fraser Government's "Uranium Decision" and the Foundations of Australian Non-Proliferation Policy: A Reappraisal*
}

\author{
MichaEl ClARKE \\ Griffith University
}

\begin{abstract}
The Fraser era represents a defining moment in Australia's approach to the issues of uranium exports and non-proliferation policy. In contrast to some well-established positions in the literature, this essay argues that the Fraser government's August 1977 decision to approve the export of uranium was framed not only by domestic political considerations stemming from the Ranger Environmental Inquiry but also by important international factors. In particular, I argue that the non-proliferation initiatives of the Carter administration presented the Fraser government with an opportunity to portray the export of Australian uranium as means to strengthen the non-proliferation regime and enhance Australia's influence.
\end{abstract}

Since 2006 the questions of whether Australia should export uranium, and to whom and under what conditions, have re-emerged as issues of some controversy in Australian politics. Two major decisions by the former Coalition government of Prime Minister John Howard (1996-2007) in particular - the convening of the Uranium Mining, Processing and Nuclear Energy Review (UMPNER) taskforce in 2006 and the approval of uranium exports to India in August 2007 - brought them back into the Australian domestic political debate in a manner unprecedented since the 1970s. The UMPNER task force was charged with developing a comprehensive review of uranium mining and processing and the potential future contribution of nuclear energy in Australia, while the decision to approve uranium exports to India overturned longstanding policy of only exporting the mineral to non-nuclear weapons states (NNWS) signatory to the Treaty on the Non-Proliferation of Nuclear Weapons (NPT). ${ }^{1}$ The subsequent electoral victory of the ALP under the leadership of Kevin Rudd in November 2007, however, resulted in the repudiation of these policy directions with the Rudd government shelving the recommendations of the UMPNER task force and overturning the uranium export agreement with India. Significantly, both of these reversals were justified on the basis of well-established arguments - that there was no clear case for the establishment of a domestic uranium enrichment industry or civil nuclear energy industry and that India was not a signatory to the NPT.

Under the ALP, Australia has returned to what might be termed its "traditional" approach to these issues whereby Australia only exports uranium to states signatory to

\footnotetext{
* The author would like to acknowledge that research for this article was conducted under an Australian Research Council Linkage Grant, LP0883246 - Australia's Nuclear Choices.

1 Michael Clarke, "Refashioning Australia's Nuclear Bargain?: The Challenges of Changing Strategic, Regime and Market Environments", Nonproliferation Review, Vol. 15, 2 (July 2008), pp.311-34.
} Classics, School of Political Science and International Studies, The University of Queensland and Blackwell Publishing Asia Pty Ltd. 
the NPT under International Atomic Energy Agency (IAEA) safeguards, and abjures the possibility of domestically processing and enriching uranium or establishing civilian nuclear power capabilities. This approach to the issues of uranium export and nuclear non-proliferation is essentially that constructed by the 1975-83 Coalition government of Prime Minister Malcolm Fraser in the late 1970s. The Fraser era represents a defining moment in Australia's approach to these issues as it was in this period that Australia became unequivocally committed to the goal of non-proliferation. This commitment was most especially demonstrated in the public justifications that the Fraser government presented for its 25 August 1977 decision to approve the further mining and export of Australian uranium. In contrast to some well established positions in the literature, this article suggests that this decision was framed not only by domestic political considerations stemming from the Ranger Environmental Inquiry but also by important international factors. In the four decades since the Fraser government's "uranium decision", the international dimension has faded from view with the treatment of the issue. Even Malcolm Fraser's recent memoirs almost exclusively focused on his attempt to balance the desire to exploit uranium with the protection of Aboriginal land rights and the environment. ${ }^{2}$

The importance of the international dimension to the Fraser government's "uranium decision" has been hinted at in previous treatments. Patrick Weller, for example, noted in his account of Fraser's prime ministership that Fraser had stated to a confidant that he wanted to establish a "domestic and international position that was unassailable" with respect to the uranium issue. ${ }^{3}$ However, Fraser's advocacy of uranium mining in Opposition and the Liberal-Country Party's traditional alignment with the interests of business subsequently resulted in the development of a dominant interpretation in the literature that his government's decision to approve uranium exports was based primarily on commercial/economic considerations. ${ }^{4}$ Indeed, Alan Renouf in his study of Australian foreign policy under Fraser asserted emphatically that "the motive was principally commercial gain" for the uranium decision. ${ }^{5}$ Yet such accounts do not take adequate account of the international dimension of the decision. Thus the subsequent discussion argues that the initiatives of the Carter administration permitted the government to argue that the export of Australian uranium would be an effective instrument to strengthen the non-proliferation regime and enhance Australia's influence. This fitted with Fraser's stated goal, noted by Weller, to present his government's uranium policy in the best possible light both domestically and internationally.

As will emerge below, the initiatives of the new US administration of President Jimmy Carter to prevent the spread of the so-called "plutonium economy" provided the Fraser government with just such an opportunity to achieve the international aspect of this equation. In particular, Carter's initiatives to move the nuclear fuel cycle away

\footnotetext{
${ }^{2}$ See Malcolm Fraser and Margaret Simons, Malcolm Fraser: The Political Memoirs (Melbourne, 2010), pp.561-69.

${ }^{3}$ Patrick Weller, Malcolm Fraser: A Study in Prime Ministerial Power in Australia (Ringwood, 1989), p.367.

4 For example see Brian Martin, "The Australian Anti-Uranium Movement", Alternatives: Perspectives on Society and Environment, Vol. 10, 4 (1982), pp.26-35; Christian Reus-Smit, "Arms Control, Nuclear Strategy and Australian Foreign Policy: The Fraser Years", Interdisciplinary Peace Research, Vol. 1, 2 (1989), pp.57-73; and Richard Broinowski, Fact or Fission: The Truth about Australia's Nuclear Ambitions (Melbourne, 2003).

${ }^{5}$ Alan Renouf, Malcolm Fraser and Australian Foreign Policy (Sydney, 1986), p.115.
} 
from plutonium opened a window of opportunity for the Fraser government to portray the export of Australian uranium as an effective mechanism through which to strengthen international non-proliferation efforts. Although this window proved to be open for only a fleeting period, it has nonetheless proved to be of pivotal importance in the foundation of Australia's approach to uranium exports and non-proliferation. As the final section of the article will demonstrate, the core assumption of the Fraser government's uranium export policy - that Australia could use its uranium as a positive incentive to induce "good" non-proliferation behaviour amongst other states - has had a remarkable longevity and continues to inform contemporary debates on this issue. Prior to exploring these issues in detail, however, it is first necessary to briefly examine the domestic and international context that formed the backdrop to the Fraser government's "uranium decision".

\section{The Domestic and International Context of the Fraser Government's "Uranium Decision"}

Australia's encounter with the nuclear age can be divided into two broad phases. The first phase from the closing years of the Second World War to the early 1970s was defined by three major themes: efforts to harness the military, strategic and economic/developmental potential of nuclear fission to Australian needs; an ambivalence towards emerging arms control initiatives; and the unfulfilled economic potential of Australia's uranium resources. ${ }^{6}$ The second phase can be dated from Australia's formal renunciation of the nuclear weapons option upon its ratification of the NPT as a non-nuclear weapons state in 1973 under the Australian Labor Party (ALP) government of Prime Minister Gough Whitlam. This period has been defined by a strong and activist commitment to the international non-proliferation regime which has conditioned Australia's exploitation of its uranium resources.

Although Australia's journey to the ratification of the NPT between 1968 and 1973 has been detailed elsewhere, it is necessary to note that it occurred in a changing domestic political context. ${ }^{7}$ While Australia signed the NPT on 19 February 1970 under the Liberal-Country Party coalition government of Prime Minister John Gorton (1968-71), it was done somewhat reluctantly. This reluctance was in no small measure due to Gorton's conviction that Australia required an independent nuclear weapons capability to ensure its security in a regional strategic context characterised by the diminution of British and US influence. ${ }^{8}$ This conviction was felt in practice during Gorton's tenure through the launching of plans for the construction of a 500 megawatt research reactor at Jervis Bay to be either fuelled by natural uranium or coupled with a uranium enrichment plant so as to limit Australian dependence on foreign supplies of

\footnotetext{
${ }^{6}$ See Wayne Reynolds, Australia's Bid for the Atomic Bomb (Melbourne, 2000); Alice Cawte, Atomic Australia (Kensington, 1992); Jim Walsh, "Surprise Down Under: The Secret History of Australia's Nuclear Ambitions", Nonproliferation Review (Fall 1997), pp.1-20; and Jacques C. Hymans, "Isotopes and Identity: Australia and the Nuclear Weapons Option", Nonproliferation Review (Spring 2000), pp.1-23.

${ }^{7}$ Christopher Hubbard, "From Ambivalence to Influence: Australia and the Negotiation of the 1968 Nuclear Non-Proliferation Treaty", Australian Journal of Politics and History, Vol. 50, 4 (2004), pp.526-543.

${ }^{8}$ The British withdrawal from "east of Suez" and US disengagement from Vietnam under the Nixon administration in particular increased Gorton's established doubts regarding the credibility of British or US security guarantees to Australia. See Christine Leah and Rod Lyon, "Three Visions of the Bomb: Australian Thinking about Nuclear Weapons and Strategy", Australian Journal of International Affairs, Vol. 64, 4 (2010), pp.465-70.
} 
nuclear fuel. Significantly, the operation of a heavy-water reactor fuelled by natural uranium would have also produced plutonium as a by-product, providing Australia with the potential to acquire sufficient fissile material to develop a nuclear weapon. ${ }^{9}$

Thus when Australia was asked in mid-1968 to sign the recently concluded NPT as a NNWS, the Gorton government's stance on the treaty was defined by ambivalence. As Walsh has argued its strategy "was simply not to sign the treaty rather than openly reject it" so as to keep Australia's nuclear options open and not come into direct conflict with the preference of its US ally. Despite this ambivalence the Gorton government signed the treaty on 19 February 1970, although the Prime Minister was himself to remark that "our decision to sign is not to be taken in any way as a decision to ratify the treaty". ${ }^{10}$ Major factors contributing to this decision were continued division within cabinet, US pressure and the late signatures of other doubters (and US allies) such as West Germany, Italy and Japan. ${ }^{11}$ Gorton's subsequent removal as Prime Minister by his colleagues in March 1971 in favour of William McMahon did not result in ratification of the NPT, although McMahon did delay plans for the Jervis Bay reactor. Within a year of McMahon's elevation to the Prime Ministership the LiberalCountry Party Coalition was voted out of office in favour of the ALP under the leadership of Gough Whitlam. The ALP had in Opposition advocated that Australia sign and ratify the NPT as a NNWS and the new prime minister moved quickly in that direction, ratifying the treaty in January 1973 and permanently shelving the plans for the Jervis Bay reactor. ${ }^{12}$

Although the Whitlam government ratified the NPT, it had won office with a prouranium mining and development stance in its platform, including a desire to maximise the economic potential of Australia's uranium by developing a uranium enrichment capability.$^{13}$ The perceived economic potential of uranium was driven by the discovery between 1970 and 1972 of four major new deposits of uranium at Nabarlek, Ranger, Koongarra and Jabiluka in the Northern Territory estimated to be some of the largest in the world. ${ }^{14}$ The desire to reap the projected economic windfall of this "uranium boom" was, however, significantly complicated for the Whitlam government by its preelection commitment to advance the land rights of Australia's Aboriginal peoples. ${ }^{15}$ These goals - maximising the economic potential of uranium and advancing Aboriginal land rights - thus intersected with some contradiction. Australia's ratification of the NPT as a NNWS, the promise of a potential uranium "boom", and Aboriginal land rights all converged to generate domestic political debate on whether or not Australia should export uranium, and if so, on what basis. To resolve these contradictions, the Whitlam government established the Ranger Uranium

\footnotetext{
${ }^{9}$ Walsh, “Surprise Down Under", pp.9-12.

${ }^{10}$ Ibid., p. 12.

${ }^{11}$ For a perspective that highlights the internal bureaucratic debate as playing the decisive role in Australia's decision see Hubbard, "From Ambivalence to Influence", pp.526-543.

${ }^{12}$ Walsh, "Surprise Down Under", pp.12-13.

13 The Whitlam government's desire for a uranium enrichment capability is examined in detail in Wayne Reynolds, “Australia's Quest to Enrich Uranium and the Whitlam Government's Loans Affair", Australian Journal of Politics and History, Vol. 54, 4 (2008), pp.562-78; see also idem, "The Yellow Cake Road: Malcolm Fraser, the Ranger Enquiry and Australia's Role in the US International Fuel Cycle Project", Australian Journal of Politics and History, Vol. 58, 4 (2011), pp.511-525, which was published subsequent to the submission of this article.

${ }^{14}$ Cawte, Atomic Australia, pp.136-137.

15 Jason O'Brien, “Canberra Yellowcake: The Politics of Uranium and How Aboriginal Land Rights Failed the Mirrar People”, Journal of Northern Territory History, Vol. 14 (2003), p. 80.
} 
Environmental Inquiry under Commissioner Justice Russell Fox in 1975 to inquire into the environmental impact of proposals to mine and mill uranium at the Ranger site.

The period of the Inquiry's hearings, opening in July 1975 and closing in March 1976, encompassed the constitutional crisis that precipitated Whitlam's dismissal from office and the appointment of the leader of the Liberal-County Party Coalition, Malcolm Fraser, as caretaker Prime Minister in November 1975. Significantly, Fraser and his Liberal and Country Party colleagues had in Opposition been vocal advocates for the immediate development of Australia's uranium for export and viewed the Ranger Inquiry as an obstacle to such a development. Thus when the Coalition won the subsequent December 1975 federal election it was assumed by many observers that uranium mining and export would be rapidly approved. However it was not until the delivery of the first of the Ranger Inquiry's reports in October 1976 and its second report in May 1977 that the Fraser government began to publicly elucidate its uranium policy.

\section{The "Uranium Decision": A "Cart it to Carter" Policy?}

The Fraser government's elucidation of its approach to uranium mining and exports and non-proliferation occurred in two major statements by the Prime Minister and other senior ministers on 24 May and 25 August 1977. The first, delivered prior to the government's final decision to approve the export of uranium in August, specified the conditions under which Australia would export uranium if the government chose to do so, thereby establishing the foundations of Australia's nuclear safeguards policy. The second consisted of major statements to parliament by both Prime Minister Fraser and then Acting Minister for Foreign Affairs, Ian Sinclair, on 25 August 1977. These latter statements presented a broader picture of the logic behind the government's final decision to approve uranium exports. A major factor influencing both the policy direction adopted in the first statement (24 May 1977) and the rhetoric of the second statement (25 August 1977) was the non-proliferation initiatives launched by the new US administration of President Jimmy Carter between March and May 1977. Significantly, the Carter administration's quest to shift the nuclear fuel cycle away from the "plutonium economy" opened a window of opportunity for Australia to have its yellowcake and eat it too by enabling the Fraser government to frame its decision to export uranium under "strict" conditions as an important and "responsible" one in the context of international efforts to combat nuclear proliferation.

During his election campaign for the White House, Jimmy Carter had distinguished himself from the preceding Nixon and incumbent Ford administrations by explicitly linking the issues of domestic nuclear energy use and non-proliferation. Throughout the campaign, Carter drew particular attention to the national and international security implications for the US of the continued spread of nuclear technology ${ }^{16}$ For Carter, the Indian "peaceful nuclear explosion" of 1974 — whereby India used plutonium derived from a Canadian-supplied research reactor to acquire the fissile material for the bomb - demonstrated the proliferation danger inherent in the further spread of ostensibly civilian nuclear technology. ${ }^{17}$ However, the oil crisis of 1973 had also stimulated

\footnotetext{
${ }^{16}$ See J. Michael Martinez, "The Carter Administration and the Evolution of American Nuclear Nonproliferation Policy, 1977-1981”, Journal of Policy History, Vol. 14, 3 (2002), p.264.

17 For the Carter administration's views see Joseph S. Nye, "Nonproliferation: A Long-Term Strategy", Foreign Affairs, Vol. 56, 3 (1978), pp.604-606. Nye was then Deputy to the Under Secretary of State for Security Assistance, Science and Technology and chaired the National Security Council Group on Nonproliferation.
} 
renewed interest in and demand for nuclear energy as a possible route to energy security with a subsequent projected rise in demand for uranium fuel to power nuclear reactors. This in turn generated questions as to the availability of uranium fuel, prompting fears that a greater reliance on nuclear power would in fact result in the replacement of dependence on one set of energy suppliers (i.e. oil suppliers) with dependence upon on another set (i.e. uranium fuel suppliers/producers). This fear, it was hoped, could be mitigated by the rapid development and use of plutonium fuel through the operation of fast, or "breeder", reactors - that would permit countries to become self-sufficient in nuclear fuel. ${ }^{18}$ However, this projected turn toward fast breeder reactor technologies as a means of combating energy insecurity held the potential to place nuclear weapons within reach of those states that were embarking on fast breeder reactor programs.

In this context the Carter administration was concerned with the proposed breeder reactor programs of allies such as Japan, West Germany and Italy as well as those of Third World states such as Pakistan. ${ }^{19}$ For the incoming Carter administration, the key to mitigating this threat to international security was to control the spread of reprocessing technology and the "plutonium economy". ${ }^{20}$ As was pointed out by contemporaneous critics, however, the Carter administration's almost exclusive focus on the proliferation potential of plutonium overlooked the fact that the major nuclear reactor types in commercial use - light-water reactors fuelled by enriched uranium and heavy-water reactors fuelled by natural uranium - produced plutonium as a byproduct of their operation. ${ }^{21}$ Additionally, the subsequent decades would demonstrate that the proliferation potential of uranium enrichment technology would be equally as dangerous as that associated with the production of plutonium and reveal the Carter administration's desire to shift the global nuclear fuel cycle to uranium enrichment technologies as something of a misstep. ${ }^{22}$

However, it was in this shifting international context that the Fraser government awaited the second Ranger Report and began to formulate its policy position. Prime Minister Fraser was quick to recognise the importance of the shifting international context. This is demonstrated in his letter to the new US President of 4 February 1977. In the letter, subsequently tabled in parliament on 23 March 1977, the Prime Minister asserted that Australia "fully" supported the objective of strengthening the nonproliferation regime and concurred with the President's warnings as to the proliferation dangers posed by spent fuel reprocessing and plutonium. ${ }^{23}$ Significantly, Fraser noted that beyond "our general commitment to non-proliferation"

\footnotetext{
${ }^{18}$ P. Andrew Karam, "How do fast breeder reactors differ from regular nuclear power plants?", Scientific American, 17 July 2006, <http://www.scientificamerican.com/article.cfm?id=how-do-fastbreeder-react>

${ }^{19}$ Antonio Tisco, "The Carter Administration and its Non-Proliferation Policies: the Road to INFCE", Humana Mente: Journal of Philosophical Studies, Vol. 16 (2011), pp.60-64.

${ }^{20}$ Martinez, "The Carter Administration”, pp.267-268.

${ }^{21}$ See for example, Mason Wilrich, "A Workable International Nuclear Energy Regime”, Washington Quarterly, Vol. 2, 2 (1979), pp.13-30.

${ }^{22}$ The exposure of the proliferation activities of the A.Q. Khan network in 2003-04 and of Iran's nuclear program, for example, would starkly demonstrate the proliferation potential of uranium enrichment technology. See Chaim Braun and Christopher Chyba, "Proliferation Rings: New Challenges to the Nuclear Non-Proliferation Regime", International Security, Vol. 29, 2 (2004), pp.549, and Christopher Clary, "The AQ Khan Network and the Limits of the Non-Proliferation Regime", Disarmament Forum, 4 (2004), pp.33-42.

${ }^{23}$ Commonwealth Parliamentary Debates (CPD), House of Representatives, 23 March 1977, p.484.
} 
Australia's particular interest - and perhaps our scope in future to exert influence on international developments - relates to our potential as a supplier of uranium. Australia would certainly want nuclear material deriving from any uranium it might supply to be subject to stringent control. ${ }^{24}$

This was a clear intimation from the Prime Minister that he perceived Australia's uranium resources as providing it with a capacity to positively affect the strength of international non-proliferation efforts. However, Fraser was also quick to assure the US President that Australia's approach in this respect would be coordinated with "like minded" countries such as the US and Canada so that nuclear safeguards policy would be "mutually reinforcing". 25

Carter's response was equally revealing. His letter to Fraser of 11 March 1977 not only thanked the Prime Minister for his "letter of support" but also provided the Prime Minister with a glimpse of his administration's policy direction by noting

[...] we are actively examining ways to provide guaranteed fuel supplies to countries which are willing to accept constraints consistent with our non-proliferation objectives. This will help to reduce proliferation by giving nations an incentive to place their nuclear facilities under international safeguards and not to acquire sensitive nuclear facilities. ${ }^{26}$

The President also appeared to concur with Fraser's presumption that Australian uranium could play a positive role in this regard by suggesting that "Australia's potential as a major supplier of uranium gives you a particular interest in this aspect [i.e. guaranteed fuel supplies] of the subject". ${ }^{27}$ Furthermore, Carter argued, if the US, Canada and Australia could "collaborate on policies for the supply of natural uranium, we can play a vital role in reducing the threat of proliferation". ${ }^{28}$

The direction of the Carter administration's efforts to prevent the further spread of the "plutonium economy" was subsequently revealed with the President's announcement of a number of changes in US nuclear policy on 7 April 1977. These included: the indefinite US deferral of commercial reprocessing and recycling of plutonium; halting plans for the liquid metal fast breeder reactor (LMFBR) program previously endorsed by the Nixon and Ford administrations; an increase in US capacity to produce enriched uranium fuels; and the imposition of an embargo on the export of enrichment and reprocessing technology. The President also indicated that the US would be exploring technical alternatives for minimising the proliferation dangers of the nuclear fuel cycle while simultaneously attempting to assure energy-deficient states such as Japan of long-term supplies of energy. ${ }^{29}$

Significantly, in response to queries from journalists after these announcements, the President publicly reiterated his belief that Australia, as a potentially "substantial" supplier of uranium, had a key role to play in assisting his administration in dissuading other states from adopting the plutonium route, and its attendant proliferation dangers, to nuclear energy. ${ }^{30}$ The President's desire to collaborate with Australia (and Canada)

\footnotetext{
${ }^{24}$ Ibid. My emphasis.

${ }^{25}$ Ibid.

${ }^{26}$ Ibid.

${ }^{27}$ Ibid.

${ }^{28}$ Ibid.

29 "Nuclear Power Policy Remarks and a Question-and-Answer Session with Reporters on Decisions Following a Review of US Policy, 7 April 1977", Public Papers of the Presidents of the United States: Jimmy Carter, January 20 to June 24, 1977, The American Presidency Project, <http://www.presidency.ucsb.edu/ws/index.php?pid=7315>.

${ }^{30}$ Ibid.
} 
on this issue was subsequently expressed through the convening of a series of discussions in April and May 1977 of senior US, Australian and Canadian officials concerning the practicality of various nuclear safeguards proposals. ${ }^{31}$ During these talks it was made clear that the Carter administration believed the export of Australian uranium would be "pivotal" in discouraging the use of plutonium. ${ }^{32}$ The full effect of the Carter administration's direction on the Fraser government's deliberations on the issue of uranium exports and their connection to nuclear proliferation was soon demonstrated in federal parliament.

Prime Minister Fraser subsequently presented his government's nuclear safeguards policy before parliament on 24 May 1977..$^{33}$ The tenor of the Prime Minister's introductory remarks demonstrated that the Carter administration's approach had served to reinforce the perception that Australia's potential as a uranium supplier could place it in a position of influence. The Prime Minister thus began by noting that while the issue of preventing the further spread of nuclear weapons "without forgoing the tangible benefits of nuclear power" was one of "major international importance" it had "added significance for Australia because of our potential as a supplier of uranium". ${ }^{34}$ Importantly, Fraser then asserted that his government was "determined that Australia should play an active role with other countries in the search for, and achievement of, joint solutions" to this international problem and reaffirmed Australia's commitment to non-proliferation arguing that the "proliferation of nuclear facilities without adequate protection against diversion of material to nuclear weapons production" was "obviously inimical to Australia's interests and to global and regional security". 35 These factors accordingly required "selectivity in the choice of customer countries and the closest attention to adequate safeguards" and that safeguards not be something "to be balanced against commercial considerations". ${ }^{36}$

These considerations were reflected in the major elements of nuclear safeguards policy that the Prime Minister presented to federal parliament. Firstly, the government recognised that strengthening and improving international nuclear safeguards was an ongoing process and Australian policy should thus be kept under regular review. Secondly, the government would establish as the "minimum requirement" for all NNWS to receive Australian uranium that they be party to the NPT and for all NWS that they give Australia assurance that nuclear material supplied by it for peaceful purposes not be diverted for military purposes. Thirdly, the Prime Minister noted that Australian-obligated uranium would be covered by IAEA safeguards from the time it left Australian ownership and nuclear material supplied by Australia would be subject to safeguards for the full life of the material. Fourthly, bilateral safeguards agreements between the Australian government and recipient countries would be required for all future contracts. Fifthly, these bilateral safeguards agreements would ensure that retransfer, enrichment or reprocessing of Australian uranium be contingent on the prior consent of the Australian government. Sixthly, importing countries would have to provide an assurance that their domestic nuclear facilities had adequate physical

\footnotetext{
${ }^{31}$ Australian Atomic Energy Commission Annual Report: 1976-77 (Canberra, 1977), p.47.

${ }^{32}$ Paul Kelly, "The Carter Connection", The National Times, 30 May-4 June 1977; and "Australian Uranium: Anthony Supports Carter", The Economist, 21 May 1977, p.93.

${ }^{33}$ The Rt Hon. Malcolm Fraser, MP, "Government Policy on Nuclear Safeguards - Ministerial Statement”, CPD (House), 24 May 1977, pp.1700-1705.

${ }^{34}$ Ibid., pp.1700-1701.

${ }^{35}$ Ibid., p. 1701.

${ }^{36}$ Ibid.
} 
security. Finally, the Prime Minister asserted that Australia would actively seek to coordinate nuclear safeguards with other "like minded" states. ${ }^{37}$ Fraser in conclusion thus argued that the "essential ingredients" of his government's policy were "careful selection of customer countries", "the application of international safeguards", "additional safeguards through bilateral agreements", and "active involvement by Australia in international efforts" to strengthen nuclear safeguards. ${ }^{38}$

However, Paul Keating, responding for the ALP Opposition, charged that the "Prime Minister's statement is so close to the thinking of the Carter Administration that one must remain cynical as to his motives for introducing it". ${ }^{39}$ For Keating the government's safeguards statement equated to "a 'Cart it to Carter' policy on the question of uranium" that was fundamentally driven by the Prime Minister's desire to "shore up what he sees as an opportunity with the American President". ${ }^{40}$ Keating's cynicism was also shared by a contemporaneous observer who noted:

In most ways, Mr Carter's statement was very useful to the Australian pro-uranium mining lobby. Mr Fraser himself was so impressed that instead of waiting for the arrival of the second Fox report, his cabinet sat for some eight hours and agreed to a set of uranium exporting conditions which closely resembled those of Mr Carter. ${ }^{41}$

That Australia did in fact have a real opportunity to establish itself as a key partner of the new US administration on the issues of uranium and non-proliferation was underlined during the Prime Minister's subsequent visit to the US in June during which President Carter asserted that joint US and Australian efforts to prevent further proliferation was "the most important new concept that binds us". ${ }^{42}$ As noted previously, Australia's importance to Carter's initiatives lay in its potential as a reliable source of natural uranium. Australia's emergence as a significant and "responsible" uranium exporter would help, it was hoped, give effect to the administration's desire to reduce the spread of the "plutonium economy" by, in the President's words, providing "guaranteed fuel supplies to countries which are willing to accept constraints consistent with our non-proliferation objectives". ${ }^{43}$ As will be demonstrated below, these goals underpinned the justifications elucidated by the Fraser government for its "uranium decision".

The Prime Minister began his statement to parliament on 25 August 1977 by declaring that after "exhaustive consideration" and "motivated by a high sense of moral responsibility" the government had decided "that there should be further development of uranium under strictly controlled conditions". ${ }^{44}$ This position was determined by the government's recognition that nuclear proliferation was the most serious potential danger stemming from a projected expansion in demand for nuclear energy and uranium. According to the Prime Minister, the response to these twin challenges "was

\footnotetext{
${ }^{37}$ Ibid., pp.1702-1704.

${ }^{38}$ Ibid., p. 1705.

${ }^{39}$ The Rt Hon. Paul J. Keating, MP, CPD (House), 24 May 1977, p.1705.

${ }^{40}$ Ibid., pp.1706-07.

41 John McCarthy, "Problems in Australian Foreign Policy, January to June 1977", Australian Journal of Politics and History, Vol. 23, 3 (December 1977), p.342.

${ }^{42}$ Cited in Henry S. Albinski, "Problems in Australian Foreign Policy - July to December 1977", Australian Journal of Politics of History, Vol. 24, 1 (April 1978), p.18.

${ }^{43}$ See President Carter's 11 March 1977 reply to Fraser in CPD (House), 23 March 1977, p.484.

${ }^{44}$ The Rt Hon. Malcolm Fraser, MP, "Australian Uranium Policy - Ministerial Statement", CPD (House), 25 August 1977, p.645.
} 
best served by Australia agreeing now to the export of uranium". ${ }^{45}$ In a situation in which "Australia possess 20 per cent of the world's known reserves of low cost uranium", Fraser continued, "we are in a special position of influence and have a corresponding moral responsibility to maximise protection against nuclear weapons proliferation by responding to the needs of many countries for adequate assurances of uranium supplies". ${ }^{46}$ Echoing the logic of the Carter administration's approach, Fraser declared that by deciding to export uranium Australia could "slow the movement towards the use of plutonium as a nuclear fuel and lessen the attendant risks of nuclear weapons proliferation". This stance would also "greatly" strengthen Australia's ability "to support more effective safeguards and minimise proliferation risks" as "[o]nly as a producer and supplier of uranium can Australia be an effective force". ${ }^{47}$ The Prime Minister then concluded his remarks by drawing together these arguments in a formulation that would in time become a bipartisan justification for the export of Australian uranium:

The export of Australian uranium will decrease the risks of further proliferation of nuclear weapons and will support and strengthen the Nuclear Non-Proliferation Treaty. It will help to make a safer world. The advent of Australia as a major supplier of uranium will make certain that Australia's voice on this most vital problem of international affairs - nuclear weapons proliferation - will be heard and will be heard with effect. ${ }^{48}$

The Acting Minister for Foreign Affairs, Ian Sinclair, then further underlined the extent of the government's embrace of the central element of the Carter administration's approach. Sinclair commenced by reiterating the four "cornerstones" of the government's nuclear safeguards policy - "strict" adherence to the NPT, IAEA safeguards, bilateral agreements between Australia and importing countries and Australian participation in multilateral efforts to strengthen safeguards and the nonproliferation regime - that had been presented to parliament by the Prime Minister on 24 May. ${ }^{49} \mathrm{He}$ continued by detailing further explanations as to the linkages between aspects of nuclear safeguards policy and the government's justification for approving the export of uranium. For the government, Sinclair observed, the NPT was the "most important international non-proliferation instrument" and its uranium export policy was designed to further the goal of achieving "universal adherence" to the Treaty. In this regard, the government's uranium export policy would make a direct contribution by offering "a tangible reward - namely access to Australian uranium" for those countries which either did not have nuclear weapons or were prepared to renounce them by signing the NPT. This "tangible incentive" was, in the government's estimation, also capable of encouraging adherence to the Treaty by "countries not at present party to it". ${ }^{50}$

\footnotetext{
${ }^{45}$ Ibid., p.646.

${ }^{46}$ Ibid., p.647. That Australia had an obligation to supply raw materials was an enduring theme in Fraser's public statements. In March 1975, for example, he argued that Australia not only had "an obligation to use our natural resources [...] for the wider good of the international community" but also "to be an assured and honest supplier of raw materials". See Malcolm Fraser, "National Objectives - Social, Economic, and Political Goals", Australian Quarterly, Vol. 47, 1 (1975), p.33.

${ }^{47}$ CPD (House), 25 August 1977, p.647.

${ }^{48}$ Ibid., p.651.

49 The Rt Hon. Ian Sinclair, MP, "Uranium Development: International Implications - Ministerial Statement”, CPD (House), 25 August 1977, p.660.

${ }^{50} C P D$ (House) 25 August 1977, p.660.
} 
Ultimately the government's policy was based on the recognition that it was "not realistic to ask countries to renounce nuclear weapons and accept stringent safeguards while denying them the means to develop nuclear energy for peaceful purposes". ${ }^{51}$ Furthermore, the issue of "assured supplies of natural and low enriched uranium" was "doubly important at the present time, because inadequacy of such supplies would reinforce the trend towards the use of technologies based on plutonium". ${ }^{52}$ Given this context, Sinclair asserted, it would be "a fundamental error to suppose that uranium export and the objective of non-proliferation are incompatible".53 In conclusion, Sinclair neatly gathered together the various strands of justification for the government's decision:

If Australia is to give effect to its stringent safeguards policy, to see innovations embodied in that policy actually incorporated in new international arrangements, and to be able to exert influence for the wider adoption by other countries of similarly rigorous policies, we must be able to speak from a position of strength. We must be seen as a country which has legitimate and direct interests and which is able to offer a tangible benefit in return for acceptance by others of these stringent controls. Far from hindering the cause of non-proliferation, uranium export, subject to the fullest and most effective safeguards, will place Australia in a position to help the development of an increasingly effective non-proliferation regime. ${ }^{54}$

In response to the Opposition's continued criticism of its approach after these announcements, Fraser was compelled to reiterate the fundamental bases of the government's position. Before parliament on 8 September, for example, Fraser stressed that the government's decision was determined on "the principal ground" of what was judged to be the best strategy with respect to preventing further nuclear proliferation. ${ }^{55}$ Significantly, he also established a key linkage between Australia's role as a "responsible" supplier of uranium and its ability to have a "voice" in international nonproliferation efforts. The Prime Minister observed that it was "quite odd" that those who shared the "common objective" of preventing proliferation:

[...] should suggest that Australia should behave as though we were on the moon or on another planet and not part of this world. Countries are going to get uranium. They will get it under less scrupulous safeguards than if some of them buy it from us. If we do not sell we will have no influence in dealing with the great task of making the world a safer place. We will have no influence in relation to proliferation and other matters of real importance. ${ }^{56}$

Such statements clearly demonstrated that the Fraser government's decision had been guided in important respects by the logic of the Carter administration's approach. In particular, the fundamental assumption of the Carter approach - that states must be offered a positive incentive to dissuade them from adopting reprocessing and plutonium production technologies - was accepted by the Fraser government. The acceptance of this position made sense for the government on a number of levels. Firstly, Australia by agreeing to the export of uranium was demonstrating its commitment to fulfilling its obligations under the NPT. Secondly, as demonstrated by the sentiments explicitly expressed by Prime Minister Fraser in his correspondence with President Carter, and in his statements to federal parliament, his government

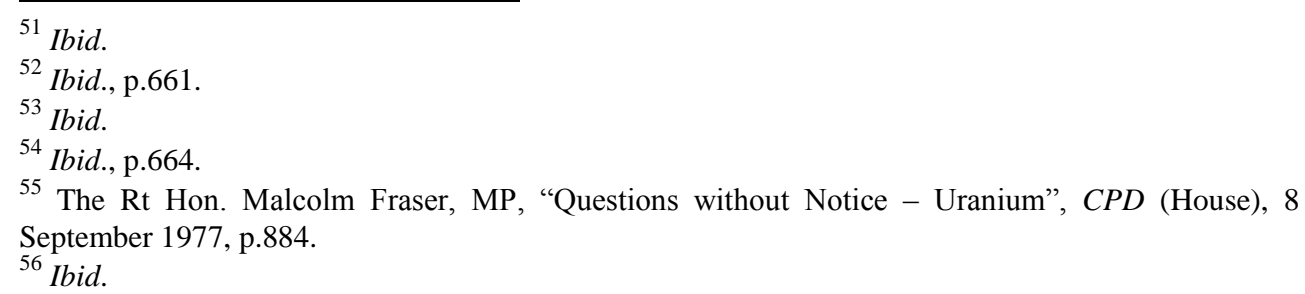


perceived that the export of uranium in this context would create a position of influence for Australia not only within its relationship with the US but also in multilateral non-proliferation efforts. Finally, this policy trajectory enabled the government to argue that its position was not only a "responsible" one but also one that made Australia a key partner of the US in attempting to prevent the further spread of nuclear weapons.

\section{The Fraser Legacy: Uranium, Non-Proliferation and the Illusion of Leverage?}

As Russell Trood has noted, the arguments presented to justify its uranium decision illustrated that the Fraser government believed that, as a country with substantial reserves of uranium, "Australia had acquired a new status and influence in the international community [...] that requires it to speak, and commands that it be heard, on issues like proliferation". 57 The most immediate expression of this belief was the Fraser government's eager participation in President Carter's International Nuclear Fuel Cycle Evaluation (INFCE) process. The INFCE, established by Carter as a multilateral effort to develop a new consensus on the structure of the international nuclear fuel cycle and appropriate safeguards measures, began its organisational meetings in Washington in October $1977 .{ }^{58}$ Australia's involvement was significant as it "sought and secured" the co-chairmanship of "Working Group 3" of the INFCE, which was concerned, appropriately enough given Australia's interests, with the issue of assurance of long-term supply of nuclear fuel. ${ }^{59}$ The INFCE, in which some sixty-six countries participated, however, was only a "technical and analytical" study of the nuclear fuel cycle and potential improvements of nuclear safeguards, and participants would, in the words of the INFCE organisational meeting's final communiqué, "not be committed to INFCE's results". ${ }^{60}$

However, the findings of the INFCE, when its final report was released in February 1980, ultimately contradicted many of the preferences of the Carter administration. ${ }^{61}$ In particular, the INFCE anticipated the possible commercial use of plutonium within two decades, took the view that states had a "right" to use plutonium in power generation, and that a state's decision to do so should be based not only on non-proliferation considerations but also on economic grounds. ${ }^{62}$ In perhaps the starkest rebuke to Carter's agenda, the INFCE “concluded that fuel cycles cannot be ranked in terms of proliferation risk, based on whether or not they employ reprocessing of spent fuel". ${ }^{6}$ This result clearly undermined the central assumption upon which the Fraser government had constructed its "uranium decision" and presented Australia with a problematic question. If the "plutonium economy" remained both a viable and internationally acceptable option for "energy deficient" states, what incentive was there

\footnotetext{
${ }^{57}$ Russell B. Trood, "Australian Uranium Exports: Nuclear Issues and the Policy Process" in Robert Boardman and James F. Keeley, eds., Nuclear Exports and World Politics: Policy and Regime (London, 1983), p.139.

${ }^{58}$ Steven J. Warnecke, "Non-proliferation and the INFCE: An Interim Assessment", Survival, Vol. 21, 3 (1979), p.117.

${ }^{59}$ Ibid., p.120; and Trood, "Australian Uranium Exports”, p.138.

${ }^{60}$ Final Communiqué of the Organizing Conference of the International Nuclear Fuel Cycle Evaluation (Washington DC, 21 October 1977).

${ }^{61}$ For reviews of the INFCE see Warren H. Donnelly, "INFCE and US Non-Proliferation Policy", Energy Policy (December 1980), pp.335-338; Ted Greenwood and Robert Haffa, "Supply-Side NonProliferation", Foreign Policy, No. 42 (Spring 1981), pp.125-40.

${ }^{62}$ Donnelly, "INFCE and US Non-Proliferation Policy", p.337.

${ }^{63}$ Greenwood and Haffa, "Supply-Side Non-Proliferation", p.131.
} 
for them to purchase uranium from Australia with "stringent" safeguards attached? In this respect it is difficult to disagree with Trood's judgement of the bind that the Fraser government thus found itself in when he suggested that there was no evidence "that the lure of Australian uranium is proving so irresistible" to those states who did not share Australia's non-proliferation concerns/commitments "that they would be willing to compromise options of further nuclear development by agreeing to Australia's conditions of purchase". ${ }^{64}$

Although much has changed with respect to the international environment in which Australia implements its uranium export and non-proliferation policies since the Fraser years, the core assumption of the Fraser government's "uranium decision" - that Australia could use its uranium as an instrument of diplomatic leverage - has remained largely unquestioned by successive governments in Canberra. The continued operation of this assumption is suggested by the handling of the brief controversy surrounding uranium exports to Russia in 2008 and ongoing domestic political debate regarding whether or not to export uranium to India. In the first instance, as the ALP government of Kevin Rudd (2007-10) contemplated ratifying a uranium deal with Russia concluded by the previous Coalition Howard government, Russian military forces invaded Georgia from the disputed territory of South Ossetia. This prompted speculation that the Rudd government could signal its displeasure with events in the Caucasus by deciding not to ratify the agreement. The Russia-Georgia conflict was in fact a major reason behind the ALP-dominated Joint Standing Committee on Treaties' decision to recommend that the government not ratify the agreement. ${ }^{65}$ However, this prompted a swift rebuke to the Rudd government from the Russian Ambassador to the effect that Moscow would view non-ratification of the agreement as "an obviously politically biased decision, which could harm the economic interest of Australia as well" ${ }^{66}$ Despite this controversy, and Australia's attempt to use uranium exports to influence Russian behaviour, the Australia-Russia uranium deal was ultimately ratified by Rudd's successor, Julia Gillard, on the sidelines of the G20 meeting with Russian President Dmitry Medvedev in Seoul in November 2010. ${ }^{67}$

While the controversy over uranium exports to India is of course of greater provenance and debate has extended across the terms of three Prime Ministers (i.e. Howard, Rudd and Gillard), the major contours of the debate nonetheless suggest that many within Australian politics believe that Australian uranium is, to use Sinclair's phrase, a "tangible incentive" capable of inducing "good" non-proliferation behaviour. For those on the "pro" side of the debate, exporting uranium to India along the lines of the deal struck between the George W. Bush administration and New Delhi in March 2006 provides a non-proliferation dividend by ensuring that at least some of India's nuclear infrastructure comes under IAEA inspections. ${ }^{68}$ However, those on the "con" side of the equation, including some prominent members of the previous Rudd

\footnotetext{
${ }^{64}$ Trood, “Australian Uranium Exports”, p.136.

${ }^{65}$ B. Packham, "Nuclear deal with Russia put on ice", Herald Sun, 19 September 2008.

${ }^{66}$ Daniel Flitton and Ben Nicholson, "Putin's ultimatum to Rudd over uranium deal", Age, 2 September 2008.

67 J. Norman, "New Risks from Australia-Russia Uranium Deal", Online Opinion, 19 November 2010, <http://www.onlineopinion.com.au/view.asp? article $=11251\rangle$.

${ }^{68}$ For this view see for example, The Hon. Alexander Downer MP, "Speech and Question and Answer Session, Energy Environment and Air Quality Policy Forum”, Los Angeles, 13 January 2007, <http://www.foreignminister.gov.au/transcripts/2007/070113_eeaqpf.html>; and Andrew Robb, "Uranium Sales to India: A Strategic Imperative", The Sydney Papers (Autumn 2008), pp.55-62.
} 
ministry, argue that by withholding uranium sales Australia strengthens nonproliferation by not "rewarding" India and retains a specific bargaining chip with which to extract concessions in line with Australia's non-proliferation preferences. ${ }^{69}$

Indeed, the Rudd government's position on uranium exports and non-proliferation was also reminiscent in both rhetorical style and content to that elucidated by the Fraser government. In August 2009, for example, then Foreign Minister Stephen Smith presented a justification for Australia's role as a uranium supplier that was remarkably similar to that presented by Fraser before federal parliament in August 1977. Smith argued that as Australia possessed "the world's largest uranium reserves" it had "both the responsibility and standing to help ensure that international nuclear cooperation serves exclusively peaceful purposes and does not contribute to nuclear weapons programs". ${ }^{70}$ Furthermore, as a consequence of this "responsibility and standing", Australia had developed "the world's strictest practices for safeguards for uranium supply", a policy, according to Smith, that "becomes increasingly relevant as countries take up nuclear energy as a means to reduce greenhouse gas emissions and secure future energy supplies". ${ }^{71}$ Thus the Rudd government's position continued to be framed by the assumption that the conditioning of uranium supply by the "world's strictest safeguards" would provide Australia with the best means of achieving its nonproliferation preferences.

The debate regarding uranium sales to India, however, appeared to take a new turn in November 2011. In an opinion piece in The Age, Prime Minister Gillard not only called upon her party to revisit the issue of uranium sales to India at its forthcoming National Conference in December but also expressed her personal opinion that "[i]t is time for Labor to modernise our platform and enable us to strengthen our connection with dynamic, democratic India" ${ }^{72}$ Such a "modernisation" of policy would be made on the basis of a potpourri of now familiar arguments: India was a democracy; uranium exports to India would "increase jobs"; and Australia would hold India to "the same standards we do of all countries for uranium export - strict adherence to International Atomic Energy Agency arrangements and strong bilateral undertakings" to ensure that its uranium would only be used for "peaceful purposes". ${ }^{73}$ While senior ministers such as Treasurer and Deputy Prime Minister, Wayne Swan, and Foreign Minister, Kevin Rudd, were reportedly supportive of the Prime Minister's position, others, primarily those on the Left of the party such as Anthony Albanese, were opposed on the basis of long-standing arguments. Backbench MP, Gavin Marshall, perhaps best summed up these arguments asserting: "It's irresponsible to sell uranium to a nuclear-armed

\footnotetext{
${ }^{69}$ See for example, The Hon. Stephen Smith, MP, "Australia and India: A New Partnership in the Asia Pacific Century", Address by the Minister for Foreign Affairs and Trade to the Indian Council of World Affairs, New Delhi, 11 September 2008,

$<h t t p: / / w w w . f o r e i g n m i n i s t e r . g o v . a u / s p e e c h e s / 2008 / 0809011$ newdelhi.html>.

70 The Hon. Stephen Smith MP, "Building Momentum: Australia, Nuclear Non-Proliferation and Disarmament", Sir Arthur Tange Lecture in Australian Diplomacy, 12 August 2009, <http://www.foreignminister.gov.au/speeches/2009/090812_tange.html>.

${ }^{71}$ Ibid.

72 Julia Gillard, “An opportunity for sound and fury to signify something”, Age, 15 November 2011, $<$ http://www.theage.com.au/opinion/an-opportunity-for-sound-and-fury-signifying-something20111114-1nfi3.html>.

${ }^{73}$ Ibid.
} 
country that has not signed the nuclear non-proliferation treaty and is also in regular conflict with another nuclear-armed power". ${ }^{74}$

These two basic lines of argument were much in evidence during debates at the ALP's subsequent December 2011 National Conference. Despite "feisty" debate, however, the Prime Minister's position prevailed, 206 votes to 185 on the floor of the conference. ${ }^{75}$ Although there has been much commentary that has either lauded or lamented this decision, it is abundantly clear that the international context has crucially influenced policy direction. ${ }^{76}$ The response of Minister for Defence, Stephen Smith, to questioning after the conference vote was revealing in this respect. Asked whether he had any qualms or fears of the potential consequences of uranium exports to India, he replied:

Absolutely not. I think this is a deeply significant decision. This will advance Australia's interests. What changed the nature of this discussion was when India entered into the India-United States Civil Nuclear Agreement in 2007. That agreement was approved by the International Atomic Energy Agency and the Nuclear Suppliers Group over the course of 2008-2009. That effectively put India under the international nuclear regulators for the first occasion and India gave a series of undertakings including a moratorium on future nuclear testing, signing up the International Atomic Energy Agency's additional protocol, splitting its civilian nuclear technology from the military program. That effectively gives you the same protections that you'd get if a country signed the Nuclear Non-Proliferation Treaty which of course has been a stumbling block for many years so far as India is concerned. ${ }^{77}$

Thus, the Gillard government has come to the same policy position on the basis of the same logic that the Howard government did when it approved uranium exports to India in August $2007 .{ }^{78}$ The logic of this position, put simply, is that in a situation in which it is inconceivable that India would sign the NPT as a non-weapons state, some international transparency via IAEA inspections and the implementation of bilateral safeguards is better than none at all. For Smith:

[...] this has been the best way of making sure that India, as it emerges as a superpower, as it takes its rightful place as the world's largest democracy and one of the three countries that will be superpowers in this century - the United States, China and India - has taken its rightful place and has voluntarily agreed to go under the governance of the International Atomic Energy Agency. That's a good thing. That's progress. That's improvement. ${ }^{79}$

As for the Fraser government over three decades ago, it remains vital for Australian policy-makers to portray their uranium export policy in the best possible light both domestically and internationally.

\footnotetext{
${ }^{74}$ Phillip Coorey and Ben Doherty, "Labor splits over decision on uranium", Age, 16 November 2011, <http://www.theage.com.au/environment/energy-smart/labor-splits-over-decision-on-uranium20111115-1nhab.html>

${ }^{75}$ Katherine Murphy, "Labor votes in favour of selling uranium to India", Age, 4 December 2011.

${ }^{76}$ For divergent reactions to the ALP's debates see, Rory Medcalf, "Uranium sales to India would spread trust, not nuclear arms", Age, 2 December 2011; and Marianne Hanson, "Selling uranium to India a blow to arms control", Canberra Times, 6 December 2011.

${ }^{77}$ Stephen Smith MP, Minister for Defence - Interview with Virginia Trioli, ABC News Breakfast, 5 December 2011, <http://www.minister.defence.gov.au/2011/12/05/minister-for-defence-interviewwith-virginia-trioli-abc-news-breakfast $>$.

${ }^{78}$ For an account of the Howard government's position see, Michael Clarke, "The Third Wave of the Uranium Export Debate: Towards the Fracturing of Australia's Nuclear 'Grand Bargain"' in Michael Clarke, Stephan Fruhling, and Andrew O'Neil, eds, Australia's Uranium Trade: The Domestic and Foreign Policy Challenges of a Contentious Export (Farnham, 2011), pp.115-119.

${ }^{79}$ Smith - Interview with Virginia Trioli.
} 